\title{
Evaluation of the Caesium-137 Activity at the Rochedo Dam, Goiás, Brazil
}

\section{Regina Nogueira ${ }^{1}$, Aline Oliveira ${ }^{2}$, Heliana da Costa $^{1}$, António Albuquerque ${ }^{3}$, and Paulo Scalize 4}

${ }^{1}$ Central-West Nuclear Science Center, National Nuclear Energy Commission, Parque Telma Ortegal, BR-60, Km 174,5, CEP 75345-000 Abadia de Goiás, GO, Brazil

${ }^{2}$ Institute of Socio-Environmental Studies, University Federal of Goiás, Av. Esperança, Chácara de Recreios, Samambaia, CEP 74690-900 Goiás, GO, Brazil

${ }^{3}$ FibEnTech - Fiber Materials and Environmental Technologies, University of Beira Interior, Faculty of Engineering, Calçada Fonte do Lameiro, 6200-358 Covilhã, Portugal

${ }^{4}$ School of Civil Engineering, University Federal of Goiás, Av. Universitária, 1499, sala 14, Setor Universitário, CEP 74605-220, Goiânia, Goiás, Brazil

Corresponding Author:

Regina Nogueira

rnogueira@cnen.gov.br

Received: 7 January 2020

Accepted: 21 April 2020

Published: 3 May 2020

Publishing services provided by Knowledge E

(c) Regina Nogueira et al. This article is distributed under the terms of the Creative Commons Attribution License, which permits unrestricted use and redistribution provided that the original author and source are credited.

Selection and Peer-review under the responsibility of the STARTCON19 Conference Committee.

\section{Abstract}

In 1987, in Goiânia (Goiás, Brazil) a radiological accident occurred due to the violation of a capsule containing Cs-137, previously used in radiotherapy equipment. The source contained caesium chloride and, due to the high solubility of this compound in water, there was contamination of people and consequent dispersion in the environment. The waste was discharged into the river network and after four years, a high concentration of Cs-137 was still observed in the sediments at the Rochedo dam, in Piracanjuba, Goiás, 80 kilometres downstream of the Metropolitan Region of Goiânia. This research analysed the Cs-137 activity in sediment samples and water samples from the Rochedo dam, with the purpose of updating the radiological monitoring data of the region and also to verify if the perceived values would indicate any threat to the environment and public health. The Cs-137 activity was detected in $93.8 \%$ of the analysed samples, whose values varied from traces to $2.25 \mathrm{~Bq} / \mathrm{L}$. The results for all water samples and for $53.8 \%$ of the sediment samples were below the minimum detectable activity by the equipment. This study showed that Cesium-137 activity seem to be very low in the water resources and sediments of the Rochedo dam and it seems to not offer radiological risks for public health and the environment.

\section{Introduction}

Caesium-137 (Cs-137) can be introduced into the environment by anthropogenic action or through radiological or nuclear accidents. The risk of its dispersion in water sources is high. The monitoring of this radial in the environment should be done regularly, especially in areas exposed to this element, since it is liable to accumulate in sediments and plants and, consequently, it may constitute a threat to public health [1].

Among the worldwide event records of Cs-137 rteleased in the environment, it is relevant to cite the accident occurred in the 1986 in the Chernobyl Power Plant (Ukraine), 
when $6.4 \times 10^{13} \mathrm{~Bq}$ of Cs-137 were dispersed in the atmosphere due to the explosion of a nuclear reactor, contaminating water, soil and vegetation [2]. More recently, in 2011, it was registered the accident of Fukushima (Japan), after a tsunami that caused or collapsed a nuclear reactor, dissipating about $1.5 \times 10^{16} \mathrm{~Bq}$ of Cs-137 [3].

Semiahon et al. [4] recorded the water contamination of the Yenisei River (central Siberia, Russia), due to the discharge of residues from an industrial nuclear power plant and mining, $60 \mathrm{~km}$ from the city center.

In the second half of 1987, in Goiânia (Goiás, Brazil), a serious radiology accident arose due to the violation of a Cs-137 capsule, previously used in a radiotherapy equipment. The source contained caesium acid and, due to its high solubility in water, there was contamination of people and dispersion in the environment [2]. The radioactive material was discharged into the Capim Puba stream, which is a tributary of the Meia-Ponte river. Ten years after the accident, a concentration of $9.4 \times 10^{10} \mathrm{~Bq}$ of Cs-137 was detected in the sediments of the Rochedo dam, in the city of Piracanjuba-GO, $80 \mathrm{~km}$ from the Metropolitan Region of Goiânia [5].

Thus, the present study aims to measure the levels of Cs-137 at the water and sediments of the Rochedo dam, in order to evaluate if there are risk for the environment and public health.

\section{Materials and Methods}

\subsection{Location of the study area}

The study was carried out at the Rochedo dam, which houses a hydroelectric power station (PCH), located on the Meia Ponte river, in the municipality of Piracanjuba, about $94 \mathrm{~km}$ from the Metropolitan Region of Goiânia (GO, Brazil), near the places where De Luca [5] made measurements in 1997.

This structure is a $5.4 \mathrm{~km}^{2}$ dam of mixed gravity of earth and concrete with $17 \mathrm{~m}$ of height and $550 \mathrm{~m}$ of length and a gross fall of $14.6 \mathrm{~m}$. It is configured by a concrete construction on the left bank and center of the riverbed, where a free sill spill is implanted, and a compacted earth dam located on the right bank. It currently operates at a flow of $33 \mathrm{~m}^{3} / \mathrm{s}$ and the $\mathrm{PCH}$ houses a generating unit with power of approximately 4.0 MW, operating since July $1955[6,7]$. 


\subsection{Sampling work}

A sampling points map was setup, which took in account the delimitation of the basin of contribution of the PCH of Rochedo Dam, using a digital terrain model (SRTM) with a spatial resolution of $30 \mathrm{~m}$, considering the highest elevations in the surroundings of the drainage areas. Afterwards, the geospatial of the sampling points was carried out. All geographic data were projected in the Datum Geocentric Reference System for the Americas 2000 (SIRGAS 2000) and Mercator's Universal Transverse Projection, in the zone 22 South, and processed in Qgis 2.18 software. The data were obtained in the portals of the State System of Geoinformation of Goiás and in the Geological Service of the United States.

The sampling work was carried out on September 24, 2018.

Sediment samples were collected at 13 points (Figure 1) and water samples at three points (upstream and downstream of the Meia Ponte river and inside the dam). The water samples were stored in polyethylene bottles and kept under refrigeration until analyzed. The sediments were collected with a carbon steel trap and stored in cotton fabric containers to facilitate removal of excess water. The depth of collection of the sediment in relation to the water level varied between 0.5 and $1.5 \mathrm{~m}$.

The sediment samples were oven dried at $100{ }^{\circ} \mathrm{C}$ for 24 hours, sieved to fraction less than $2 \mathrm{~mm}$ and accommodated in polyethylene bottles for further analysis [8].

The identification and quantification of Cesium-137 was performed by gamma spectrometry, using a hyperpure germanium detector (HPGe), the most suitable equipment for the measurement of radioactivity at low levels [9]

The samples were read using a Canberra spectrometer, with a superaxial Germanium coaxial detector, model GX2518, with relative efficiency of $25 \%$, pre-amplifier model 2002 CSL and Genie-2000 software. The counting time was 15 hours and the results of the concentration of Cesium-137 activity are presented in Becquerel per kilogram (Bq / $\mathrm{kg}$ ) of wet mass.

\section{Results and Discussion}

Table 1 shows the Cs-137 values observed in each sediment sample. It can be observed that five samples had values between 0.86 and $2.246 \mathrm{~Bq} / \mathrm{Kg}$ and for the others samples the values were below the minimum detectable activity (MDA) by the equipment. All results are well away from the limit value of $104 \mathrm{~Bq} / \mathrm{Kg}$ of Cs-137 concentration, established by the CNEN PR-3.01-001 [10] as a threat for public health and the environment. 

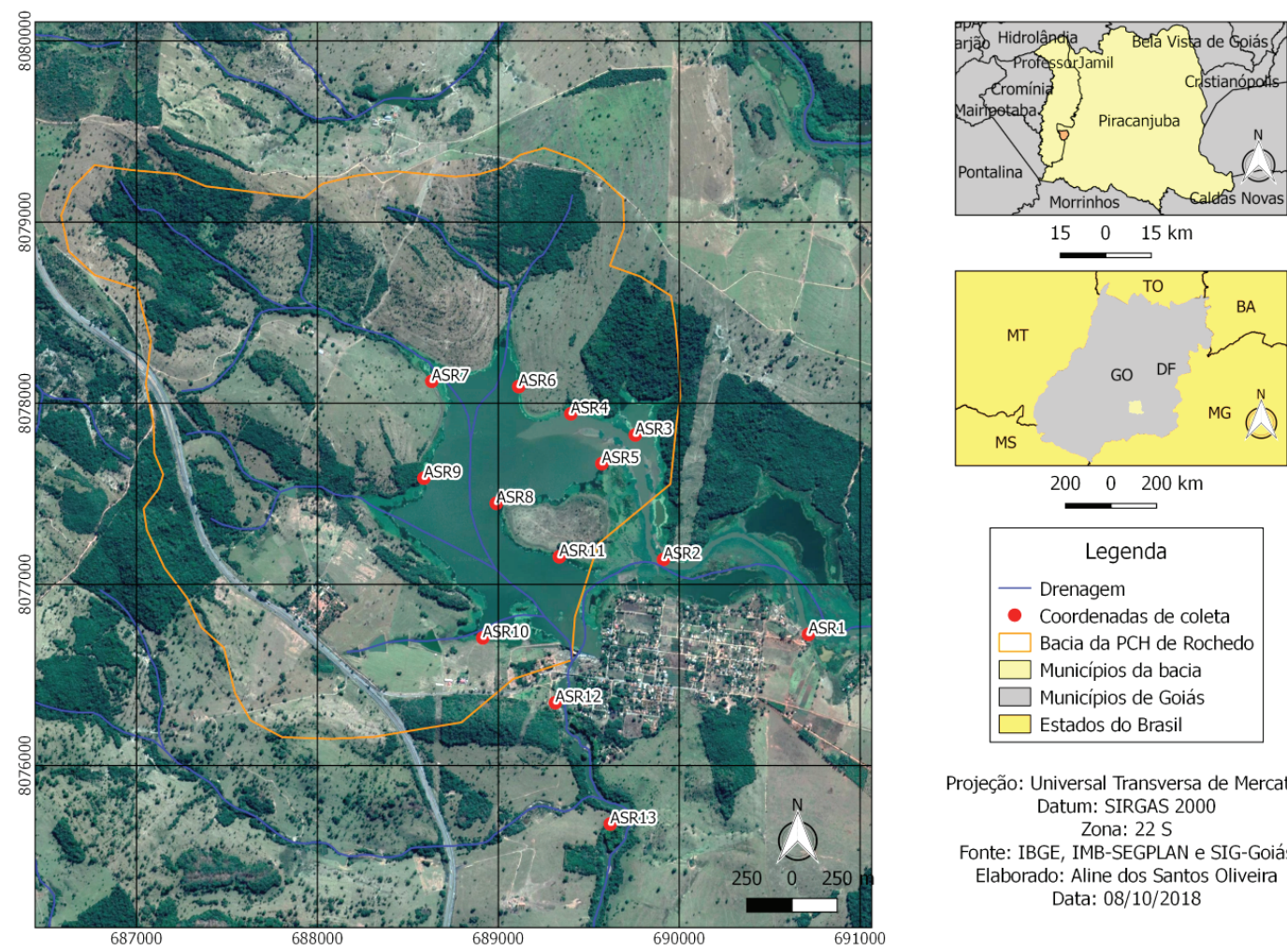

Projeção: Universal Transversa de Mercator Datum: SIRGAS 2000 Zona: $22 \mathrm{~S}$
Fonte: IBGE, IMB-SEGPLAN e SIG-Goiás
Elaborado: Aline dos Santos Oliveira

Figure 1: Location of sampling points for water and sediments.

TABLE 1: Cs-137 concentrations for the sediment's samples.

Sample
ASR-01
ASR-02
ASR-03
ASR-04
ASR-05
ASR-06
ASR-07
ASR-08
ASR-09
ASR-10
ASR-11
ASR-12
ASR-13

\begin{tabular}{|c|}
\hline Wet mass $(\mathrm{Kg})$ \\
\hline 1.090 \\
1.018 \\
\hline 1.270 \\
1.044 \\
0.910 \\
0.538 \\
0.638 \\
0.982 \\
1.544 \\
0.896 \\
\hline 0.584 \\
\hline 0.888 \\
\hline 1.176 \\
\hline
\end{tabular}

\begin{tabular}{|c|}
$\begin{array}{c}\text { Minimum Detectable } \\
\text { Activity of Cs-137 } \\
\text { (Bq/Kg) }\end{array}$ \\
\hline 0.766 \\
\hline 0.795 \\
\hline 0.542 \\
\hline 0.765 \\
\hline 0.934 \\
\hline 0.998 \\
\hline 1.097 \\
\hline 0.939 \\
\hline 0.480 \\
\hline 0.969 \\
\hline$*$ \\
\hline
\end{tabular}

$\begin{gathered}\text { Cs-137 activity } \\ (\mathbf{B q} / \mathrm{Kg})\end{gathered}$
0.860
$<$ MDA
$<$ MDA
0.789
$<$ MDA
$<$ MDA
2.246
1.497
$<$ MDA
1.194
$*$
$<$ MDA
$<$ MDA

MDA: minimum detectable activity

According to the World Health Organization [11], the concentration of Cs-137 lower than $10 \mathrm{~Bq} / \mathrm{L}$ in drinking water do not cause radiological risk to human health. Table 2 shows the results of the analysis of Cs-137 for the water samples collected around 
the dam. All values are below the minimum detectable activity (AMD) and below the recommended reference.

TABLE 2: Cs-137 concentrations for the water samples.

Sample
Upstream the dam
Dam
Downstream the dam

$\begin{gathered}\text { Minimum Detectable Activity } \\ \text { of Cs-137 (Bq/L) }\end{gathered}$
0.427
0.389
0.401

Cs-137 activity (Bq/Kg) $<$ MDA $<$ MDA $<$ MDA

MDA: minimum detectable activity

DE LUCA (1997) [5] estimated that $9.4 \times 1010$ Bq of Cesium-137 reached the Rock dam ten years after the radiological accident in Goiânia, suggesting that the concentration of this radioisotope would be decreasing due to the natural transport mechanisms of the sediment out of the dam. By adding these data to the results obtained in the present work, it can be seen that there was a significant reduction of the levels of Cesium -137 in the river water and the dam, and in the sediments of the dam, in the last 31 years.

This research showed that, at the present time, it seems that there is no significant contamination of the water and sediments in Rochedo dam the due to the 1987 accident. Therefore, water uses from the dam are not compromised, but monitoring actions should continue until the values of Cs stabilized.

\section{Conclusions}

The results obtained in this study show the presence of Cs-137 activity in $93.8 \%$ of the sediment samples. Quantifiable values of this radioisotope were observed in 31.3\% of the total samples, ranging from 0.789 to $2.246 \mathrm{~Bq} / \mathrm{L}$. The results for $100 \%$ of the water samples and for $53.8 \%$ of the sediment samples were below the minimum detectable activity by the measurement equipment. Taking into account the limits of radioisotope activity that pose a risk to public health, it can be concluded that the values found are below the exclusion, exemption and dispensation criteria as a protection requirement for radiological hazards to the public health and the environment.

\section{References}

[1] M. Miranda, P. Neto, E. Farias et al. Césio-137 em solos de Unidades de Conservação do Estado de São Paulo, International Joint Conference 2017. Goiânia, Braszil, (2017). 
[2] IAEA. The Radiological Accident in Goiania, International Atomic Energy Agency, Vienna, Austria (1988).

[3] K. Hirose, Fukushima Dai-ichi nuclear power plant accident: summary of regional radioactive deposition monitoring results, J. of Env. Radioactivity, 111: 13-17 (2012).

[4] T Semizhon, S. Rollin, Y. Spasova, E. Klemt, Transport and distribution of artificial gamma-emitting radionuclides in the River Yenisei and its sediment, J. of Env. Radioactivity, 101: 385-402 (2010).

[5] M. De Luca, J. Godoy, Mobilization studies of 137Cs in sediments from Rochedo Reservoir, Studies in Environmental Science, Elsevier, 68: 119-128 (1997).

[6] D. Znamensky, Barragens e aproveitamentos hidrelétricos de Jaó e Rochedo sobre o rio Meia Ponte em Goiás: Lições não esquecidas de acidentes e incidentes, XXVI Seminário Nacional de Grandes Barragens. Goiânia, Brasil, (2005).

[7] CELG, Geração e Transmissão. Repor available in: http://celggt.com/Infraestrutura. aspx?4 (consulted in September 2018).

[8] U.S. Department of Energy, The Procedures Manual Of The Environmental Measurements Laboratory, HASL-300, Volume I, 28th ed., New York, USA, (1997).

[9] K. Ferreira, Determinação das doses efetivas de alimentos, água e solo na região do CAUB I através da espectrometria de raios gama, MSc Thesis, Faculty of Biomedical Engineering, University of Brasília, Brasilia, Brazil (2018).

[10] CNEN, Diretrizes Básicas de Radioproteção, Comissão Nacional de Energia Nuclear, CNEN PR-3.01-001. Rio de Janeiro, Brazil, (2011).

[11] WHO, Management of radioactivity in drinking-water, World Health Organization, (2018). 